\title{
Trace Elements in Children with Acute Lymphoblastic Leukemia
}

\author{
Omid Reza Zekavat, Mehran Karimi, Fereshteh Majidi, Mohammadreza \\ Bordbar, Sezaneh Haghpanah, Shirin Parand, Haleh Bozorgi*
}

\begin{abstract}
Objective: Although combined chemotherapy regimen leads to $80 \%$ remission in children with acute lymphocytic leukemia (ALL), malnutrition and altered serum trace elements as a consequence of chemotherapy agents, have become the new issue to deal with. With the aim to evaluate each trace element in childhood ALL, we investiguâtes six main trace elements before and after induction chemotherapy while considering age, gender and chemotherapy protocol as confounding factors. Methods: Thirty-six newly diagnosed ALL children were recruited, and trace elements were assessed by atomic absorption spectrometry technique. Trace elements (Zinc, Copper, Manganese, Magnesium, Chromium and Iron) decreased significantly after induction chemotherapy. Results: Considering the confounding factors, mean difference of elements decreased significantly, except for Chromium. Its mean difference was only significant in children younger than 10 and those who had received standard risk chemotherapy. Conclusion: In conclusion, all the studied trace elements decreased significantly after induction chemotherapy session in ALL children. This highlights the importance of complementary and supplementary management. A larger cohort study with longer follow up is warranted to elucidate the long-term effect of chemotherapy on these trace elements on the general health status, quality of life or risk of relapse in ALL children.
\end{abstract}

Keywords: Trace elements, acute- lymphoblastic leukemia- chemotherapy

Asian Pac J Cancer Prev, 22, Anticancer Activity of Natural Compounds: HOW's on Methods and Reports Suppl, 43-47

\section{Introduction}

Acute leukemia is one of the most prevalent malignancies before the age of 15 , comprising $34 \%$ of all cancer cases in children. Although many genetic and environmental factors are associated with acute leukemia, the cause remains to be unidentified. Chemotherapy combined regimen leads to $80 \%$ remission in children with acute lymphoblastic leukemia (ALL), making its recurrence and quality of life (QoL) as issues to deal with (Sitaresmi et al., 2008; Onciu, 2009; Hunger and Mullighan, 2015).

Infection and malnutrition are the main threats affecting QoL. Chemotherapy along with ALL can cause malnutrition in patients, which is manifested by recurrent infections, necessiting longer period of hospitalization that leads to overall poorer outcome

(Papadopoulou et al., 1997; Sgarbieri et al., 2006; Hunger and Mullighan, 2015).

Trace elements such as Zinc $(\mathrm{Zn})$, Copper $(\mathrm{Cu})$, Manganese (Mn), Magnesium (Mg), Chromium (Cr) and Iron $(\mathrm{Fe})$ have verified roles in gene expression and cellular immune functions. They also play a role in cellular protection against free radical injuries as well as being a risk factor in malignancies (Sgarbieri et al., 2006). Many studies evaluated the possible correlation between trace elements and cancers, especially ALL and elements such as $\mathrm{Zn}$ were even introduced as an adjuvant therapy (Silvera and Rohan, 2007; Alkufi, 2015; Wiemels, 2015; Mehrzad et al., 2018).

A recent study reported that most parents of children with ALL use trace elements and other supplements without the physicians' order. The controversial role of these elements in malignancies highlights the importance of monitoring them following therapies to provide better outcome and survival rate (Hassan et al., 2017).

The aim of this was to evaluate serum trace elements level amongst children with ALL before and after chemotherapy induction, considering the confounding factors such as age, gender and protocols, with the intention to provide better management during the course of treatment and follow up.

\section{Materials and Methods}

\section{Patients}

This cohort study was conducted on newly diagnosed children with ALL, confirmed via bone marrow aspiration and biopsy, flowcytometry and immunohistochemistry tests. Forty patients who were admitted to tertiary 
Oncology hospital affiliated to Shiraz University of Medical Ssciences were randomly recruited from January 2016 to April 2018, Shiraz, Iran. Those with previous chemotherapy and malignancies, consumption of supplementary drugs within the last 6 months before diagnosis, chronic gastrointestinal diseases requiring treatment, and any condition which required supplementary intakes were excluded. Two patients were excluded from the study, and 38 patients with age frequency matching less than 10 and $\geq 10$ years were included in this study.

A written informed consent was obtained from their parents or legal guardians who had accepted to participate in this study. This study was approved by the local Ethics Committee of Shiraz University of Medical Sciences with the code number of IR.SUMS.MED.REC.1396.28.

\section{Sampling and laboratory data}

Fifteen ml venous blood was taken after fasting for 8 hours from each patient before commencing chemotherapy. Plasma was extracted and frozen, solution containing elements was evaporated, using flame burning with air and acetylene in 2000 degrees Celsius (14 days after blood sampling). Next, the atoms were neutralized and absorbed by the cathode lamp. $\mathrm{Zn}, \mathrm{Cu}, \mathrm{Mn}, \mathrm{Mg}, \mathrm{Fe}$ and $\mathrm{Cr}$ serum levels were assessed, using flame atomic absorption (AA-220FS model made in USA by Varian Spectra company) spectrometer equipped with deuterium background correction. Each trace element normal range according to our laboratory kits are as follow: Fe (22-155 $\mu \mathrm{g} / \mathrm{dl}), \mathrm{Zn}(56-134 \mu \mathrm{g} / \mathrm{dl}), \mathrm{Cu}(100-166(\mu \mathrm{g} /$ dl), $\mathrm{Mg}(1.5-2.5 \mathrm{mg} / \mathrm{dL}), \mathrm{Mn}(>3 \mathrm{ng} / \mathrm{ml}), \mathrm{Cr}(0.1-1.2$ $\mu \mathrm{g} / \mathrm{L})$. The elements were re-measured after completing chemotherapy induction, and again before starting the maintenance chemotherapy for each patient.

\section{Chemotherapy regimen}

Based on ALL type and each individual's condition, one of the high or standard risk protocol was used. High risk protocol consists of induction of remission (one month), consolidation ( 9 weeks), interim maintenance 1 (7 weeks), delayed intensification 1 ( 8 weeks), reconsolidation (4 weeks), and maintenance (20-32 months). Standard risk protocol include induction of remission (one month), consolidation (one month), interim maintenance (one month), delayed intensification (two months), and maintenance (20-32 months) (Lanzkowsky et al., 2016).

\section{Statistical analysis}

Data were analyzed by IBM SPSS software version 21. Descriptive data were presented as mean, standard deviation and 95\% confidence interval. Comprising of trace elements serum levels before and after chemotherapy was conducted by Paired t-test. P-values $<0.05$ were considered to be statistically significant.

\section{Results}

Thirty-eight patients with ALL were recruited. Two patients expired due to chemotherapy complications and 36 patients finished the study. Mean age of participants was $8.41 \pm 4.88$ years, and $47.2 \%$ of them were females.

All serum trace elements following chemotherapy induction decreased significantly (Table 1).

None of the patients experienced Fe or $\mathrm{Mg}$ deficiency before and after chemotherapy, but $10.5 \%$ of them developed $\mathrm{ZN}, \mathrm{Cu}$ and $\mathrm{Cr}$ deficiencies after chemotherapy. Mn deficiency was observed in $5.31 \%$ of patients before starting chemotherapy regiments, which increased to $6.73 \%$ after treatment.

Trace element mean differences were assessed according to gender and age, before and after chemotherapy (Table 2).

In both age and gender groups, all trace elements decreased significantly, except $\mathrm{Cr}$, which decreased significantly amongst patients younger than 10 years old. Similarly, all trace elements decreased significantly following both standard-risk and high-risk chemotherapy regimens, except for serum $\mathrm{Cr}$, showing a remarkable reduction amongst the standard-risk group and not the high-risk category (Table 3).

\section{Discussion}

In the current study, we observed a significant decrease in all measured trace elements after chemotherapy induction. The only element that was deficient before starting the treatment was Mn. Moreover, deficiency was also detected in $\mathrm{Zn}, \mathrm{Cr}$ and $\mathrm{Cu}$ just after chemotherapy induction.

Trace elements with less than $0.01 \%$ of the total body weight, are vital for basic cellular mechanisms. With the defined roles, altered serum level of the main

Table 1. Mean Serum Levels of the Measured Trace Elements before and after Chemotherapy in Children with Leukemia

\begin{tabular}{lcccc}
\hline Trace elements & $\begin{array}{c}\text { Pre-chemotherapy } \\
\text { mean } \pm \text { SD }\end{array}$ & $\begin{array}{c}\text { Post-chemotherapy } \\
\text { mean } \pm \text { SD }\end{array}$ & $\begin{array}{c}\text { Mean difference } \\
\text { (95\% confidence interval) }\end{array}$ & P-Value \\
\hline $\mathrm{Fe}(\mu \mathrm{g} / \mathrm{dl})$ & $195 \pm 85.27$ & $129.94 \pm 63.44$ & $-65.05(-100.18$ to -29.93$)$ & $0.001^{*}$ \\
$\mathrm{Zinc}(\mu \mathrm{g} / \mathrm{dl})$ & $182.23 \pm 63.40$ & $79.94 \pm 22.20$ & $-102.29(-121.34$ to -83.23$)$ & $<0.001^{*}$ \\
$\mathrm{Copper}(\mu \mathrm{g} / \mathrm{dl})$ & $188.04 \pm 80.48$ & $101.28 \pm 38.42$ & $-86.75(-120.01$ to -53.5$)$ & $<0.001^{*}$ \\
$\mathrm{Mg}(\mu \mathrm{g} / \mathrm{dl})$ & $2.84 \pm 0.46$ & $2.22 \pm 0.28$ & $-0.61(-0.82$ to -0.41$)$ & $<0.001^{*}$ \\
$\mathrm{Mn}(\mu \mathrm{g} / \mathrm{L})$ & $3.61 \pm 1.47$ & $2.46 \pm 0.82$ & $-1.15(-1.59$ to -0.70$)$ & $<0.001^{*}$ \\
$\mathrm{Cr}(\mu \mathrm{g} / \mathrm{L})$ & $0.34 \pm 0.12$ & $0.29 \pm 0.10$ & $-0.04(-0.08$ to -0.002$)$ & $0.037^{*}$ \\
\hline
\end{tabular}

*, Statistically significant; Zinc, (Zn); Copper, (Cu); Manganese, (Mn); Magnesium, (Mg); Chromium, (Cr); Iron, (Fe) 
Table 2. Age- and Gender-Stratified Mean Difference of Serum Trace Elements Pre- and Post-Chemotherapy

\begin{tabular}{|c|c|c|c|c|c|c|c|c|}
\hline \multirow{2}{*}{$\begin{array}{l}\text { Trace } \\
\text { elements }\end{array}$} & \multicolumn{4}{|c|}{ Gender } & \multicolumn{4}{|c|}{ Age } \\
\hline & $\begin{array}{c}\text { Female } \\
\mathrm{n}(17) \\
\text { Mean difference } \\
(95 \% \mathrm{CI})\end{array}$ & $P$-Value & $\begin{array}{c}\text { Male } \\
\text { n (19) Mean } \\
\text { difference } \\
(95 \% \mathrm{CI})\end{array}$ & $P$-Value & $\begin{array}{l}<10 \text { years } \\
\text { n }(20) \text { Mean } \\
\text { difference } \\
(95 \% \mathrm{CI})\end{array}$ & $P$-Value & $\begin{array}{c}\geq 10 \text { years } \\
\text { n }(16) \text { Mean } \\
\text { difference } \\
(95 \% \mathrm{CI})\end{array}$ & $P$-Value \\
\hline $\mathrm{Fe}$ & $\begin{array}{c}-69.7 \\
(-123.45 \text { to }-15.95)\end{array}$ & $0.014 *$ & $\begin{array}{c}-60.89 \\
(-111.9 \text { to }-9.88)\end{array}$ & $0.022 *$ & $\begin{array}{c}-55.5 \\
(-110.09 \text { to }-0.9)\end{array}$ & $0.047 *$ & $\begin{array}{c}-77 \\
(-123.55 \text { to }-30.44)\end{array}$ & $0.003^{*}$ \\
\hline $\mathrm{Zn}$ & $\begin{array}{c}-122.99 \\
(-152.77 \text { to }-93.21)\end{array}$ & $<0.001 *$ & $\begin{array}{c}-83.76 \\
(-107.47 \text { to }-60.05)\end{array}$ & $<0.001^{*}$ & $\begin{array}{c}-107.91 \\
(-139.31 \text { to }-76.5)\end{array}$ & $<0.001 *$ & $\begin{array}{c}-95.26 \\
(-116 \text { to }-73.92)\end{array}$ & $<0.001 *$ \\
\hline $\mathrm{Cu}$ & $\begin{array}{c}-88.76 \\
(-129.33 \text { to }-48.19)\end{array}$ & $<0.001 *$ & $\begin{array}{c}-84.96 \\
(-140.42 \text { to }-29.50)\end{array}$ & $0.005^{*}$ & $\begin{array}{c}-88.16 \\
(-126.16 \text { to }-50.16)\end{array}$ & $<0.001^{*}$ & $\begin{array}{c}-85 \\
(-148.46 \text { to }-21.53)\end{array}$ & $0.012 *$ \\
\hline $\mathrm{Mg}$ & $\begin{array}{c}-0.62 \\
(-0.98 \text { to }-0.25)\end{array}$ & $0.002 *$ & $\begin{array}{c}-0.61 \\
(-0.85 \text { to }-0.37)\end{array}$ & $<0.001 *$ & $\begin{array}{c}-0.57 \\
(-0.89 \text { to }-0.25)\end{array}$ & $0.001 *$ & $\begin{array}{c}-0.67 \\
(-0.93 \text { to }-0.4)\end{array}$ & $<0.001^{*}$ \\
\hline $\mathrm{Mn}$ & $\begin{array}{c}-0.85 \\
(-1.35 \text { to }-0.34)\end{array}$ & $0.002 *$ & $\begin{array}{c}-1.41 \\
(-2.16 \text { to }-0.66)\end{array}$ & $0.001 *$ & $\begin{array}{c}-0.85 \\
(-1.34 \text { to }-0.64)\end{array}$ & $0.001 *$ & $\begin{array}{c}-0.9 \\
(-1.48 \text { to }-0.32)\end{array}$ & $0.004 *$ \\
\hline $\mathrm{Cr}$ & $\begin{array}{c}-0.04 \\
(-0.11 \text { to } 0.02)\end{array}$ & 0.182 & $\begin{array}{c}-0.04 \\
(-0.1 \text { to } 0.01)\end{array}$ & 0.119 & $\begin{array}{c}-0.05 \\
(-0.1 \text { to }-0.007)\end{array}$ & $0.027 *$ & $\begin{array}{c}-0.03 \\
(-0.03 \text { to } 0.04)\end{array}$ & 0.424 \\
\hline
\end{tabular}

*, Statistically significant; Zinc, (Zn); Copper, (Cu); Manganese, (Mn); Magnesium, (Mg); Chromium, (Cr); Iron, (Fe)

trace elements were reported to be associated with many fetal diseases such as ALL. Not only cancer, but also chemotherapy itself impairs nutritional status causing depletion of macro- and micro nutrients (Demir et al., 2011; Khuder et al., 2012; Alkufi, 2015; Modaressi et al., 2015).

$\mathrm{Zn}$ as a key component in regulating cellular functions

Table 3. Comparison of the Mean Difference of Serum Trace Elements between High-Risk and Standard-Risk Groups

\begin{tabular}{|c|c|c|c|}
\hline \multirow[b]{2}{*}{ Chemotherapy } & \multirow[b]{2}{*}{$\begin{array}{l}\text { Trace } \\
\text { elements }\end{array}$} & \multicolumn{2}{|c|}{ Mean difference } \\
\hline & & $\begin{array}{c}\text { (95\% confidence } \\
\text { interval) }\end{array}$ & $P$-Value \\
\hline Standard risk & $\mathrm{Fe}$ & $\begin{array}{c}-55.59 \\
(-105.81 \text { to }-7.36)\end{array}$ & $0.026^{*}$ \\
\hline \multirow[t]{5}{*}{$\mathrm{n}(22)$} & $\mathrm{Zn}$ & $\begin{array}{c}-109.02 \\
(-137.46 \text { to }-80.59)\end{array}$ & $<0.001^{*}$ \\
\hline & $\mathrm{Cu}$ & $\begin{array}{c}-81.71 \\
(-126.13 \text { to }-53.66)\end{array}$ & $<0.001^{*}$ \\
\hline & $\mathrm{Mg}$ & $\begin{array}{c}-0.62 \\
(-0.92 \text { to }-0.32)\end{array}$ & $0.001 *$ \\
\hline & $\mathrm{Mn}$ & $\begin{array}{c}-1.34 \\
(-1.97 \text { to }-0.7)\end{array}$ & $0.001 *$ \\
\hline & $\mathrm{Cr}$ & $\begin{array}{c}-0.04 \\
(-0.13 \text { to }-0.0004)\end{array}$ & $0.048^{*}$ \\
\hline High risk & $\mathrm{Fe}$ & $\begin{array}{c}-78.35(-132.49 \text { to } \\
-24.21)\end{array}$ & $0.008^{*}$ \\
\hline \multirow[t]{5}{*}{$\mathrm{n}(14)$} & $\mathrm{Zn}$ & $\begin{array}{c}-91.7 \\
(-115.51 \text { to } 67.9)\end{array}$ & $<0.001^{*}$ \\
\hline & $\mathrm{Cu}$ & $\begin{array}{c}-81.82 \\
(-152.94 \text { to }-10.69)\end{array}$ & $0.027^{*}$ \\
\hline & $\mathrm{Mg}$ & $\begin{array}{c}-0.61 \\
(-0.89 \text { to }-0.32)\end{array}$ & $<0.001^{*}$ \\
\hline & $\mathrm{Mn}$ & $\begin{array}{c}-0.85 \\
(-1.5 \text { to }-0.19)\end{array}$ & $0.015^{*}$ \\
\hline & $\mathrm{Cr}$ & $\begin{array}{c}-0.04 \\
(-0.13 \text { to } 0.04)\end{array}$ & 0.332 \\
\hline
\end{tabular}

*, Statistically significant; Zinc, (Zn); Copper, $(\mathrm{Cu})$; Manganese, (Mn); Magnesium, (Mg); Chromium, (Cr); Iron, (Fe) such as responding to oxidative stress and repairing damaged DNA, has been studied in many malignancies including ALL. This element was even assessed as a marker for predicting response to chemotherapy (Ho et al., 2003; Abdalla, 2016). Mehrzad et al., (2018) study on ALL patients, suggested that $\mathrm{Zn}$ could improve post chemotherapy recovery. Eby et al., (2005) used Zn as an adjuvant to chemotherapy and concluded that it would accelerate recovery from chemotherapy side effects. A research by Demir et al., (2011) showed significant lower level of $\mathrm{Zn}$ in children with ALL in comparison with normal children, emphasizing on the further evaluation of this element in ALL patients. It is worth mentioning that our patients did not suffer from $\mathrm{Zn}$ deficiency before chemotherapy, but we observed the highest decrease amongst trace elements in $\mathrm{Zn}$ following chemotherapy. Also, female patients appeared to be more at risk of losing this element. The same alteration of $\mathrm{Zn}$ serum level was previously observed after-chemotherapy (Federico et al., 2001).

Iron plays a dual role in malignancies and has been shown to have a carcinogenic role in vivo (Toyokuni, 2009). Elevated serum iron level was observed in patients with acute leukemia, disposed to fungal infections (Fenaux and Rose, 2009). Iron overload was reported in $14 \%$ of patients with ALL by Halonen et al., (2003). Regarding the stated role of iron, some physicians use iron chelators as part of treatment (Estrov et al., 1987). As opposed to the aforementioned study, our patients had reduced serum Fe level and developed iron deficiency after chemotherapy induction. Patients older than 10 years and those who were treated with high risk protocol lost more iron after chemotherapy (78.35 vs 55.59), which might be due to low level of blood transfusion amongst our patients.

$\mathrm{Cu}$ is an element, studied widely in malignancies. Its higher level was detected in patients with lymphoma, but a significant decrease was noticed after therapy and serum level remained within the normal range during remission. An increase in $\mathrm{Cu}$ level was assumed as a predictor for relapse. As for leukemia, normal amounts of $\mathrm{Cu}$ were observed in children during remission, and alteration of 
this element was reported in the active form of leukemia (Federico et al., 2001).

Our results were in line with the aforementioned result, which showed that $\mathrm{Cu}$ significantly decreased after the first chemotherapy induction. The element was not affected by factors of age, gender and chemotherapy protocol.

While Alkufi et al., (2015) reported significant increase of $\mathrm{Cu}$ serum level amongst patients with ALL, a comparative study between these patients and healthy individuals revealed lower level of $\mathrm{Cu}$ amongst patients with ALL (Khuder et al., 2012; Alkufi, 2015). Similarly, our patients developed copper deficiency after chemotherapy induction.

$\mathrm{Mg}$ was one of the least affected elements, with no report of deficiency before or after chemotherapy induction. Demir et al. reported higher level of this element after treatment, which was in contrast with our results. They also observed that patients with ALL had lower Mg serum level, which was also reported by Afridi et al. They linked the higher level of $\mathrm{Mg}$ after chemotherapy with release of this element from destroyed cell, proposing that $\mathrm{Mg}$ could be used as a predictor index in patients with ALL in response to chemotherapy (Demir et al., 2011; Afridi et al., 2018).

Diminished Mn serum level amongst patients with ALL was previously reported by several researchers (Kanabrocki et al., 1967; Mulay et al., 1971; Demir et al., 2011). Our study was also in line with the aforementioned studies, showing Mn deficiency even before initiating chemotherapy, which got worse after, suggesting that this element should be monitored closely to provide better supplement therapy in these patients.

$\mathrm{Cr}$ in patients with ALL has not been fully evaluated, but did not appear to be a risk factor for children with leukemia. Exposure to this toxic element was suggested to be a risk factor in inducing malignancies amongst teenagers (Yang et al., 2009; Whitehead et al., 2015). Although our patients had significant reduction of this element after chemotherapy induction, when we did the stratified analysis according to gender, no significant decrease was observed. Also, similar results were obtained in 10 years old or older patients and those who had high risk chemotherapy protocol. This might be partly explained by the difference in the physiologic metabolism of $\mathrm{Cr}$ in different age groups as well as the possible impact of the severity of illness or the intensity of chemotherapy protocol on the absorption, excretion or catabolism of this trace element.

This is one of the few plenary studies on trace elements amongst patients with ALL, considering the confounding factors. Despite its strengths, our study faced some limitation, such as number of participants and no further follow-up after measuring the elements following chemotherapy induction. This can be accomplished in a longitudinal study with more participants.

In conclusion, all the studied trace elements decreased significantly after chemotherapy induction amongst children with ALL. This highlights the importance of complementary and supplementary management. A larger cohort study with longer follow up is warranted to elucidate the long-term effect of these trace elements on the general health status, QoL or risk of relapse in patients with ALL.

\section{Acknowledgments}

This study was retrieved from doctor Fereshteh Majidi pediatric residency thesis with the specified grant number of 94-01-01-9229 provided by Shiraz University of Medical Sciences. The authors wish to thank Mr. H. Argasi at the Research Consultation Center (RCC) of Shiraz University of Medical Sciences for his invaluable assistance in editing this manuscript.

\section{Author contribution}

Omid Reza Zekavat: he helped with designing the study and provided the needed assessments, also, edited the final version.

Mehran Karimi: designed the study, edited the final version

Fereshteh Majidi: collected data

Mohammadreza Bordbar: reviewed the paper

Sezaneh Haghpanah : analyzed data and edited paper Shirin Parand, collected data

Haleh Bozorgi collected data, , edited the final version and helped through designing and conducting the survey

All author reads an approved the final version.

\section{Statement conflict of Interest}

The authors declare that they have no conflict of interest.

\section{References}

Afridi HI, Kazi TG, Talpur FN (2018). Correlation of Calcium and Magnesium levels in the biological samples of different types of acute leukemia children. Biol Trace Elem Res, 86, 395-406.

Alkufi HK (2015). Determination the levels of Zinc and Copper in patients with leukemia. Int J Curr Microbiol Appl Sci, 4, 812-6.

Demir C, Demir H, Esen R, et al (2011). Altered serum levels of elements in acute leukemia cases in Turkey. Asian Pac J Cancer Prev, 12, 3471-4.

Eby GA (2005). Treatment of acute lymphocytic leukemia using zinc adjuvant with chemotherapy and radiation-a case history and hypothesis. Med Hypotheses, 64, 1124-6.

Estrov Z, Tawa A, Wang X-H, et al (1987). In vitro and in vivo effects of deferoxamine in neonatal acute leukemia. Blood, 69, 757-61.

Federico A, Iodice P, Federico P, et al (2001). Effects of selenium and zinc supplementation on nutritional status in patients with cancer of digestive tract. Eur J Clin Nutr, 55, 293.

Fenaux P, Rose CJBr (2009). Impact of iron overload in myelodysplastic syndromes. Blood Rev, 23, 15-9.

Halonen P, Mattila J, Suominen P, et al (2003). Iron overload in children who are treated for acute lymphoblastic leukemia estimated by liver siderosis and serum iron parameters. Pediatrics, 111, 91-6.

Hassan T, Qureshi W, Bhat SA, et al (2017). Study of serum levels of trace elements (selenium, copper, zinc, and iron) in breast cancer patients. Int J Clin Oncol Cancer Res, 2, 82-5.

Ho E, Courtemanche C, Ames BN (2003). Zinc deficiency induces oxidative DNA damage and increases p53 
expression in human lung fibroblasts. J Nutr, 133, 2543-8.

Hunger SP, Mullighan CG (2015). Acute lymphoblastic leukemia in children. $N$ Engl J Med, 373, 1541-52.

Kanabrocki E, Case L, Graham L, et al (1967). Non-dialyzable manganese and copper levels in serum of patients with various diseases. J Nuclear Med, 8, 166.

Khuder A, Bakir MA, Solaiman A, et al (2012). Major, minor, and trace elements in whole blood of patients with different leukemia patterns. Nukleonika, 57, 389-99.

Lanzkowsky P, Lipton JM, Fish JD (2016). Lanzkowsky's manual of pediatric hematology and oncology, Academic Press. 18, pp 379-382.

Mehrzad V, Mahmood-Zadeh M, Feizi A, et al (2018). Determination relation of the Zinc serum level in acute leukemia adult patients with mucositis and neutropenic prevalence before and after treatment in Isfahan'SeyedAl-Shohada Hospital, 2012-2013. Adv Biomed Res, 7, 31.

Modaressi A, Hadjibabaie M, Shamshiri A, et al (2015). Trace elements $(\mathrm{Se}, \mathrm{Zn}$, and $\mathrm{Cu}$ ) levels in patients with newly diagnosed acute leukemia. Int J Hematol Oncol Stem Cell Res, 6, 5-10.

Mulay IL, Roy R, Knox B, et al (1971). Trace-metal analysis of cancerous and non-cancerous human tissues. J Nat Cancer Instit, 47, 1-13.

Onciu M (2009). Acute lymphoblastic leukemia. Hematol Oncol Clin North Am, 23, 655-74.

Papadopoulou A, MacDonald A, Williams M, et al (1997). Enteral nutrition after bone marrow transplantation. Arch Dis Childhood, 77, 131-6.

Sgarbieri UR, Fisberg M, Tone LG, et al (2006). Nutritional assessment and serum zinc and copper concentration among children with acute lymphocytic leukemia: a longitudinal study. Sao Paulo Med J, 124, 316-20.

Silvera SAN, Rohan TE (2007). Trace elements and cancer risk: a review of the epidemiologic evidence. Cancer Causes Control, 18, 7-27.

Sitaresmi MN, Mostert S, Gundy CM, et al (2008). Health-related quality of life assessment in Indonesian childhood acute lymphoblastic leukemia. Health Qual Life Outcomes, 6, 96.

Toyokuni S (2009). Role of iron in carcinogenesis: cancer as a ferrotoxic disease. Cancer Sci, 100, 9-16.

Whitehead TP, Ward MH, Colt JS, et al (2015). Dust metal loadings and the risk of childhood acute lymphoblastic leukemia. J Exp Sci Environ Epidemiol, 25, 593.

Wiemels J (2015). New insights into childhood leukemia etiology. Eur J Epidemiol, 30, 1225-7.

Yang Y, Tian Y, Yan C, et al (2009). Determinants of urinary 8-hydroxy-2'-deoxyguanosine in Chinese children with acute leukemia. Environ Toxicol Int J, 24, 446-52.

\section{(c) (1) ()}

This work is licensed under a Creative Commons AttributionNon Commercial 4.0 International License. 